\title{
A Correlation between Students' Rewriting of the Story in Film and Their Vocabulary Mastery
}

\author{
Rohdearni Wati Sipayung', Marhaeni K. D. Matondang ${ }^{2}$ \\ ${ }^{1,2}$ Faculty of Teacher Training and Education, Universitas Simalungun, Indonesia \\ mailto:dearsipayunk@gmail.com,mailto:kdewi6353@gmail.com
}

\begin{abstract}
This research is focused on a correlation between students' rewriting of the story in film and their vocabulary mastery at the second grade of SMP Taman Siswa Pematangsiantar. The problem of this study is: 'Is there any correlation between students' rewriting of the story in film and their vocabulary mastery?' The objective of this study are: 1) To examine whether there is a significant correlation between students' rewriting of the story in film and their vocabulary mastery; 2) To find out the contribution of watching film in improving students' rewriting of the story in film and their vocabulary mastery. From the data anlysis it can be concluded that: 1) above it can be concluded that the average score of that students' rewriting of $\neg$ the story in film variable $(X)$ is 67, 56 (4054: 60). Six students (10\%) get excellent level, 13 students $(21,6 \%)$ get very good, 13 students $(21,6 \%)$ get good, 8 students $(13,33 \%)$ get fair, 11 students $(18,33 \%)$ get poor and 9 students $(15 \%)$ get very poor; 2) The average score of the students' ability in writing recount text is 71, 52 (4291: 60). Five students $(8,33 \%)$ get excellent level, 11 students $(18,33 \%)$ get very good, 20 students (33,3\%) get good, 14 students (23,3\%) get fair, 7 students $(11,6 \%)$ get poor and 3 students $(5 \%)$ get very poor; 3$)$ There is a significant correlation between students' rewriting of the story in film variable $(X)$ and the vocabulary mastery variable $(Y)$. This result is obtained from the computation of the correlation between students' rewriting of the story in film variable $(X)$ and the vocabulary mastery variable $(Y)$ applied to the sample is 0.338 (from the calculation). The critical value of the Pearson $r$ with the $5 \%$ significant level is 0.211 (From the table of statistical book). It means that the result obtained from the computation is greater than its critical value. Therefore, I conclude that the correlation between the two variables above is highly significant.
\end{abstract}

Keywords vocabulary; rewriting story; film

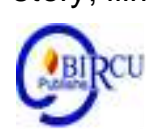

\section{Introduction}

Language is a tool for communication. English is a second language in Indonesia. However, most students are still having lack of interest in learning English. Learning through media can be one of the solutions to increase students' interest in learning English. The media that can be used in learning English are films, television, books, radio, etc. It means that there is no limitation of learning English.

Film is one of the audiovisual media in learning English. Bazalgette, C (1989) cited in Watson stated that television, film, video, radio, photograph, popular music, printed materials, and computer software can increase children's critical understanding. This means that film is a language learning media that can build students' critical understanding. 
In order to build critical understanding, students should understand the language used in the film.

However, in Indonesia, film is still not widely used as a tool in learning English in public schools. For example in SMP Taman Siswa Pematangsiantar, there is a TV and DVD player in the library but it is not used to learn English. This situation is really ironic, since the schools already have the tool for learning English but it is not used effectively. Moreover, TV can be used as a media to increase students' interest in learning English since there are sounds and pictures on it. By using the TV to show a film, the media can create English learning in interesting way.

Geddes \& Sturtridge (1982) noted 'that students' visual and critical awareness would increase through watching film activity". Through watching films, students are expected to understand what happened in the film and try to retell the story in the film. In order to retell the story in the film, students have to master the vocabulary used in film. It means that students' rewriting of the story in the film deals with students' vocabulary mastery.

Subtitle is a tool to help the students understand of the language used in the film. It also can be a media in learning vocabulary. A research conducted by Patricia S. Konskinen \& friends revealed that television program with subtitle could help students improve their vocabulary acquisition. In this study the film that is going to use is English film with Indonesian subtitle.

In this study, students have to retell the story in the film by writing it down in a piece of paper. Writing is an activity in generating ideas and thoughts in a written form. Basic reading and writing instruction can provide children with a simple vocabulary and certain skills of literary. In learning to organize informational content for writing, students gain insight into how authors handle complex ideas on paper.

Vocabulary is very important in order to understand English. Nunan, cited in Surniati (2006) stated that one o f important parts in the acquisition of the second language is the development of a rich vocabulary.

Jung (cited in Setiawandi, 2006) also stated that "\{the researchers and learners have recognized vocabulary use and development as a major aspect of learning new language.'

The amount of vocabulary is also affecting the understanding of communication. River, cited in Ermayanti (2006) stated. "The acquisition of an adequate vocabulary is essential for successful second language use, because without extensive vocabulary, we will unable to use the structures and the functions that we may have learned for comprehensible communication.

Based on the theory mentioned above, this study is going to investigate whether there is any correlation between students' rewriting of the story in the film and their vocabulary mastery. Through watching film, students are expected to rewrite the story in film and improve their vocabulary mastery. This is due to difficulties in writing, vocabulary and grammar. In addition to the difficulties that frequently found in the thesis writing of scientific is the equivalent of the words that are not suitable and contain various meanings and expressions (Redemittel) that are less academic or not varied (Hafniati, 2020).

There are some options which can be chosen by the students including the pictures, movies, videos, and games. Then, the students also like some activities such as, listening to L1 speakers; having a course book and small group work; reading newspaper; and going on excursions (Siregar, 2020). 


\section{Review of Literatures}

\subsection{Film}

Film is a term that encompasses individual motion pictures, the field of film as an art form, and the motion picture industry. Films are produced by recording images from the world with cameras, or by creating images using animation techniques or special effects. In language learning, film is one of audiovisual material in a form of video.

According to Stempleski \& Tomalin (1990:3) the interest of children and adults will occur quickly when the language is experience in a lively way through television and video. The help of moving picture and sound builds the interest. In addition, the videos can also help the students to develop their skills in learning English such as listening, speaking, reading and writing skills. Giving certain activities by using video materials can develop the four skills.

Film can be one of audiovisual material to learn English better since there are combination of sound and picture on it. "Audiovisual media are closer to real life because visual clues and context make it possible to "view" the message as much as listen to it' (Baltova, 1994: 508, cited in Danan 2004). In addition, students' exposure to digitized images such as film, television, video, is improving students' listening comprehension since there is face-to-face interaction with native speakers (Herron et. al., 1995 in Danan 2004).

Film also has communicative value in learning English. According to Lonergan (1984), the outstanding feature of video films is their ability to present complete communicative situations. The combination of sound and vision is dynamic, immediate, and accessible. This means that the communication shown in context. Film as audio-visual media has a special benefit in learning English. Lonergan (1984) stated that "the benefit of using audio-visual recording with moving pictures-such as film, television or video offers the phonetic and prosodic advantages of audio, as well as the paralinguistic information provided by the visual elements".

Paralinguistic information is gained through paralinguistic features namely arm movements, facial gestures, and eye contact. Through paralinguistic features the speaker grasp the meaning from the dialogue partner. Visual elements are also important in getting the meaning of the situation shown in the audio-visual media. Visual elements are components of the verbal and non-verbal interactions, which come to full comprehension (Holec 1975, in McGovern 1983).

Films as mass medium have similar advantages as television as far as motion and manipulation of time are concerned. Motion is essential for comprehending certain concepts and messages. For example, science experiments, operation of machines or industrial plants can be shown effectively with motion. Both the media show few hours long event in few minutes.

The emotional impact left by films helps in shaping personal and social attitudes. They present the situation in a dramatic, recreation form which brings reality also and assures the involvement of the viewer and leaves emotional impact.Films preserve modern sense of privacy and anonymity. Man has longed for invisibility and the absence of responsibility it confers, and film satisfies precisely this with. In watching a film we view a magically reproduced world while remaining invisible to it.

Film is a versatile medium. If lends itself to instructional use in both large and small groups, and for individual study. Technically, film allows a wider range of colors than video; furthermore, the colors vary more in terms of hue and portray a greater range of contrast then television. This holds viewer's attention better than video or television. 
Films provide for viewing of phenomena at extremely close range or from a vast distance, which is not possible in television. Films can be used for variety of purposes such as entertainment, education, persuasion, changing motivation and opinions. The messages conveyed through films are retained better due to its reality element. They allow for a creative production approach. It is possible to make different language and cultural versions of a film.

\subsection{Sulbtitle}

Subtitle is textual versions of the dialog in films and television programs, usually displayed at the bottom of the screen. According to Lever H.J, there are two types of subtitles, intralingua and interlingua subtitling. Intralingua subtitling deals with the production of subtitles that remain in the same language as the original and are used for the deaf or hard of hearing, or for language

learners. On the other hand, interlingua subtitling refers to both a change in mode and language, going from one language into another language and from spoken dialogue into a written, condensed translation which appears on the screen.

Interlingua subtitle is the type of subtitle used in this research. According to Danan (2004) audiovisual material enhanced with captions or interlingua subtitles is a particularly powerful pedagogical tool which can help improve the listening comprehension skills of second-language learners. Subtitling is helping the students visualize what they hear, especially if the input is not too far beyond their Linguistic ability. Subtitling can also increase language comprehension and leads to additional cognitive benefits, such as greater depth of processing.

The subtitle is expected to make the students easier to understand the meaning of the dialogues in the film. Since the students have to rewrite the story in the film, the subtitle is one of the helpful tools for the students to grasp the meaning of the dialogues in the film. The subtitle of the film is in Indonesian language form.

\subsection{Writing}

a. The Nature of Writing

Writing defines as a complex process of exploring writer's thoughts and ideas, and makes them visible and concrete. The thoughts that implemented in a written form can be examined, reconsider, added to, rearranged and changed When students feel that writing is a process, it will encourage them to think and learn. (Ghait, 2002). In line with Gaith, Harris (1969) stated that writing is an integrated process.

Furthermore, little exposure to writing will make this skill seen as a difficult skill to learn. Kay \& Dudley-Evans (1998), cited in Kim (2007) stated that, there is no doubt that writing tasks can be more difficult than other language skills, so students at low level of proficiency absolutely need something that they can rely on since they have little exposure to English writing.

The process of writing of the story in film is the process of comprehending the story and composing their comprehension in written words. Composing and comprehending are two sides of the same basic. Comprehending is critical because it requires the learner to reconstruct the structure and meaning of ideas expressed by another writer. (http:// revolution. All best.ru/ pedagogics/ 00019269 0. html).

\subsection{Vocabulary Mastery}

One of the most important things to help learners to communicate successfully is knowledge of vocabulary. The richer vocabulary we have, the better we can communicate. Hence, in order not to fail on the way of teaching and learning vocabulary, teachers and 
students must try their best to find out an appropriate method for themselves. Using visual aids, especially movies and video, is a good way to teach vocabulary and really important, necessary for the new method of teaching and learning. This chapter aims at providing some theoretical background of the study with two sections. The first one is some basic knowledge of vocabulary and the second discusses the matter of using movies and video.

As among the three dimensions of language, vocabulary, grammar and phonology, vocabulary stands out as the primacy forming the ground for the development of other skills. Vocabulary seems to be a simple and familiar concept to understand clearly, however it is really hard to give its exactdefinition. Broadly defined, vocabulary is knowledge of words and words meaning. This definition offer vocabulary's meaning on the whole, however, vocabulary is more complex than this definition suggests.

\subsection{Related Studies}

The research conducted by Baltova shows that there is a positive effect of film with subtitle as representation of written translation and images in vocabulary learning. In the research, Baltova (1999) examined the effects of viewing a French video with either French audio and French subtitles (bimodal format), or English audio and French subtitles (reversed format) on students' vocabulary learning. Another research conducted by Markham $(1989: 39,41)$ shows that the captions or subtitle help students to perform beyond their proficiency level. The students' responses were very good when the subtitle had been available.

In regard to the previous studies, this study is conducted in order to investigate the correlation between students' rewriting of the story in film and their vocabulary mastery. The film used is film with subtitle and the story is narrative.

\subsection{Concluding Remark}

Based on the above mentioned theories and related studies, this research is conducted in order to investigate students' rewriting of the story in film and also their vocabulary mastery. Students' rewriting of the story in film with subtitle can be built by gaining the audio and visual information in the film. The information from the film can be gained through the visual elements and also the subtitle.

\section{Research Methods}

\subsection{Method of the Res earch}

Research methodology is needed in any research to find out how the correlation between two variables. In this study the two variables are the rewriting of the story in film (variable $\mathrm{X}$ ) and vocabulary mastery (variable $\mathrm{Y}$ ). Research methodology is a guide in our investigation since it deals with the ways to conduct the research.

The technique used in this research is correlation analysis technique. This technique is used to find out the correlation degree between the independent variable (students' rewriting of the story) and the dependent variable (vocabulary master y). This technique is used to find out the correlation degrees between the investigated variables. This technique will describe how far the variants in one variable influence other variable.

\subsection{Population and Sample}

The population of this research is second grade students of SMP Taman Siswa Pematangsiantar. In this research the technique used to collect the sample was simple random sampling technique. Thirty students were collected randomly from 6 classes, from VII A until VII F. As Roscoe, cited in Sugiyono (2007) stated that for a research the number of 
sample is 60 is representative enough. This technique was used in order to get a good generalization of the research.

\subsection{Instruments}

\section{a. Writing Test}

This test is used to find out students' rewriting of the story in film test. The test will be conducted by asking the students to rewrite the story in the film, which titled Charlie and the Chocolate Factory. There will be five criteria to be scored; they are content, vocabulary, spelling, generic structure, and grammar, which adapted from Brown (1994: 356-358)

\section{b. Vocabulary Mastery Test}

This test given is an objective test in multiple-choice questions with four possible answers (a,b,c,d), completion, puzzle, and matching form to measure the students vocabulary mastery. The vocabulary questions are based on the vocabulary used in the film.

\subsection{Data Collection}

In order to collect the data, the instruments of the research should be tested to measure the validity and reliability.

\subsection{The Index of Difficulty (Felicity Value) and Index of Discrimination (D)}

The counting of index of difficulty and index of discrimination were used in order to find out the degree of difficulty and differences of each questions in a test instrument.

According to Arikunto, cited in Palapah 2004, the criteria of index of difficulty $(\mathrm{FV})$ are as follow.

$$
\begin{aligned}
& \text { FV } 0.00-0.30 \text { difficult } \\
& \text { FV } 0.30-0.70 \text { medium } \\
& \text { FV } 0.70-1.00 \text { easy }
\end{aligned}
$$

The result of Index of Discrimination (FV) shows that there were four questions at the easy level; one question at the difficult level and forty-five questions were at the medium level. Since most of the questions were at the medium level, the questions were considered appropriate to be used for the test.

Arikunto, cited in Palapah 2004, states that the criteria of Index of discrimination (D) are:
D: $0.00-0.20$ : poor
D: $0.20-0.40$ : satisfactory
D : $0.40-0.60:$ good
D: $0.70-1.00$ : very good

The result of Index of Discrimination (D) shows that most of the questions were considered satisfactory while the rest were considered very good, good, and poor.

\subsection{Data Analysis}

The steps to carry out this study are as follows:

1. Normality analysis was used to examine the distribution score of the two variables tested in this research. The normality analysis was examined using SPSS 15.0, the interpretation is that if sig. > 0.05, then Ho is accepted or the distribution of the data is normal.

2. Correlation analysis

a. The Distribution scores of the two variables; students' rewriting of the story in film variable $(\mathrm{X})$ and the vocabulary mastery variable $(\mathrm{Y})$. 
b. The significant examination of students' rewriting of the story in film to vocabulary master $y$. To determine correlation coefficient this research was used the Pearson formula, which calculated using SPSS 15.0. Next the result of correlation coefficient will be tested for significant by comparing the r-counted and $r$-table. The correlation is significant if $r$-counted $>r$-table

3. Direction of correlation coefficient between students' rewriting of the story in film variable $(\mathrm{X})$ and the vocabulary mastery variable $(\mathrm{Y})$.

\section{Discussion}

\subsection{Discussion}

The purpose of the data analysis in this research is meant to measure the significant correlation between students' rewriting of the story in film variable (x) and the vocabulary mastery variable (y) of the second grade students of SMP Taman Siswa Pematangsiantar. To measure those things, it is important to take the preparatory measurement.

In order to make the classification of the scores level easier, the writer made the classification.

It can be concluded that the average score of the students' rewriting of the story in film variable is $67,56(4054: 60)$. Six students $(10 \%)$ get excellent level, 13 students $(21,6 \%)$ get very good, 13 students $(21,6 \%)$ get good, 8 students $(13,33 \%)$ get fair, 11 students $(18,33 \%)$ get poor and 9 students $(15 \%)$ get very poor.

After having counted the mean score of the students' rewriting of the story in film , then the writer continue to count the mean score of students vocabulary mastery.

The average score of the students' ability in vocabulary is 71, 52 (4291: 60). Five students $(8,33 \%)$ get excellent level, 11 students $(18,33 \%)$ get very good, 20 students ( 33,3 $\%)$ get good, 14 students ( $23,3 \%)$ get fair, 7 students $(11,6 \%)$ get poor and 3 students $(5 \%)$ get very poor.

Table 1. The Square and Multiplied of $x$ and $y$

\begin{tabular}{|c|c|c|c|c|c|}
\hline $\begin{array}{c}\text { Students' } \\
\text { Number }\end{array}$ & $\mathrm{X}$ & $\mathrm{Y}$ & $\mathrm{X}^{2}$ & $\mathrm{Y}^{2}$ & $\mathrm{XY}$ \\
\hline 1 & 82 & 95 & 6724 & 9025 & 7790 \\
\hline 2 & 56 & 40 & 3136 & 1600 & 2240 \\
\hline 3 & 60 & 75 & 3600 & 5625 & 4500 \\
\hline 4 & 44 & 60 & 1936 & 3600 & 2640 \\
\hline 5 & 70 & 75 & 4900 & 5625 & 5250 \\
\hline 6 & 36 & 57 & 1296 & 3249 & 2052 \\
\hline 7 & 90 & 89 & 8100 & 7921 & 8010 \\
\hline 8 & 44 & 68 & 1936 & 4624 & 2992 \\
\hline 9 & 82 & 90 & 6724 & 8100 & 7380 \\
\hline 10 & 82 & 85 & 6724 & 7225 & 6970 \\
\hline 11 & 54 & 64 & 2916 & 4096 & 3456 \\
\hline 12 & 76 & 90 & 5776 & 8100 & 6840 \\
\hline 13 & 90 & 93 & 8100 & 8649 & 8370 \\
\hline 14 & 80 & 85 & 6400 & 7225 & 6800 \\
\hline 15 & 76 & 75 & 5776 & 5625 & 5700 \\
\hline 16 & 42 & 47 & 1764 & 2209 & 1974 \\
\hline 17 & 90 & 87 & 8100 & 7569 & 7830 \\
\hline 18 & 80 & 80 & 6400 & 6400 & 6400 \\
\hline
\end{tabular}




\begin{tabular}{|c|c|c|c|c|c|}
\hline 19 & 76 & 74 & 5776 & 5476 & 5624 \\
\hline 20 & 42 & 78 & 1764 & 6084 & 3276 \\
\hline 21 & 90 & 85 & 8100 & 7225 & 7650 \\
\hline 22 & 80 & 70 & 6400 & 4900 & 5600 \\
\hline 23 & 76 & 60 & 5776 & 3600 & 4560 \\
\hline 24 & 56 & 75 & 3136 & 5625 & 4200 \\
\hline 25 & 86 & 63 & 7396 & 3969 & 5418 \\
\hline 26 & 60 & 66 & 3600 & 4356 & 3960 \\
\hline 27 & 56 & 78 & 3136 & 6084 & 4368 \\
\hline 28 & 46 & 65 & 2116 & 4225 & 2990 \\
\hline 29 & 56 & 77 & 3136 & 5929 & 4312 \\
\hline 30 & 60 & 60 & 3600 & 3600 & 3600 \\
\hline 31 & 90 & 70 & 8100 & 4900 & 6300 \\
\hline 32 & 46 & 70 & 2116 & 4900 & 3220 \\
\hline 33 & 82 & 81 & 6724 & 6561 & 6642 \\
\hline 34 & 62 & 55 & 3844 & 3025 & 3410 \\
\hline 35 & 76 & 72 & 5776 & 5184 & 5472 \\
\hline 36 & 70 & 64 & 4900 & 4096 & 4480 \\
\hline 37 & 46 & 55 & 2116 & 3025 & 2530 \\
\hline 38 & 60 & 75 & 3600 & 5625 & 4500 \\
\hline 39 & 56 & 49 & 3136 & 2401 & 2744 \\
\hline 40 & 52 & 87 & 2704 & 7569 & 4524 \\
\hline 41 & 80 & 65 & 6400 & 4225 & 5200 \\
\hline 42 & 42 & 75 & 1764 & 5625 & 3150 \\
\hline 43 & 94 & 60 & 8836 & 3600 & 5640 \\
\hline 44 & 60 & 75 & 3600 & 5625 & 4500 \\
\hline 45 & 76 & 57 & 5776 & 3249 & 4332 \\
\hline 46 & 56 & 89 & 3136 & 7921 & 4984 \\
\hline 47 & 80 & 68 & 6400 & 4624 & 5440 \\
\hline 48 & 60 & 90 & 3600 & 8100 & 5400 \\
\hline 49 & 60 & 75 & 3600 & 5625 & 4500 \\
\hline 50 & 76 & 60 & 5776 & 3600 & 4560 \\
\hline 51 & 56 & 75 & 3136 & 5625 & 4200 \\
\hline 52 & 80 & 57 & 6400 & 3249 & 4560 \\
\hline 53 & 80 & 89 & 6400 & 7921 & 7120 \\
\hline 54 & 76 & 70 & 5776 & 4900 & 5320 \\
\hline 55 & 76 & 81 & 5776 & 6561 & 6156 \\
\hline 56 & 76 & 55 & 5776 & 3025 & 4180 \\
\hline 57 & 56 & 72 & 3136 & 5184 & 4032 \\
\hline 58 & 76 & 64 & 5776 & 4096 & 4864 \\
\hline 59 & 56 & 55 & 3136 & 3025 & 3080 \\
\hline 60 & 80 & 75 & 6400 & 5625 & 6000 \\
\hline Total $(\Sigma)$ & 4054 & 4291 & 287860 & 316231 & 293792 \\
\hline
\end{tabular}

To interpret the research findings, the writer used the Pearson Product Moment Correlation Formula to compute the data that have been obtained as follows:

$\mathrm{N}: 60$

$\sum X: 4054$

$\sum Y: 4291$ 


$$
\begin{aligned}
\sum \mathrm{X}^{2}: & 287860 \\
\sum \mathrm{Y}^{2}: & 316231 \\
\sum \mathrm{XY}: 293792 & \\
\left(\sum \mathrm{X}\right)^{2}: 16434916 & \left(\sum \mathrm{Y}^{2}: 18412681\right. \\
r_{x y} & =\frac{N \cdot \sum x y-\left(\sum x\right)\left(\sum y\right)}{\left.\sqrt{\left(N \cdot \sum x^{2}\right)-\left(\sum x\right)^{2}\left(N \cdot \sum y^{2}-\left(\sum y\right)^{2}\right)}\right]} \\
= & \frac{(60)(293792)-(4054)(4291)}{\sqrt{(60 x 287860)-(16434916)} x(60 x 316231-(18412681)} \\
= & \frac{17627520-17395714}{\sqrt{(17271600-16434916) x(18973860-18412681)}} \\
= & \frac{231806}{\sqrt{836684 x 561179}} \\
= & \frac{231806}{685222,2} \\
= & 0,338
\end{aligned}
$$

From the computation above, it was obtained that $r_{x y}$ is 0.338 and then $r_{x y}$ is consulted to the critical value for $r$ table of Product Moment to examine whether $r_{x y}$ value is significant or not. The value of $\mathrm{r}$ table with $\mathrm{N}=60$ and the $5 \%$ significant level is 0.211 (from $\mathrm{r}$ table). Therefore, it can be concluded that $r_{x y}$ is greater than $r$ table in the other words, 0.338 is greater than 0.211. Relating to that matter, she takes a conclusion that there is a correlation between students' rewriting of the story in film variable (X) and the vocabulary mastery variable $(\mathrm{Y})$ of the second grade students of SMP Taman Siswa Pematangsiantar.

\subsection{Determination Coefficient}

Interpreting the strength of the relationship between the two variables through the correlation coefficient is not sufficient. It is, therefore, necessary to compute the determination index $\mathrm{r} 2$ ( $\mathrm{R} 2$ in the table below). It is labeled determination index because $100 \%$ of the variation within the dependent variable $\mathrm{Y}$ can be accounted for by the relationship with the independent variable $\mathrm{X}$ if linear regression $\mathrm{Y}$ on $\mathrm{X}$ exists. In this case, determination index shows us the percentage of variation students' rewriting of the story in film variable $(\mathrm{X})$ and the vocabulary mastery variable $(\mathrm{Y})$ of the second grade students of SMP Taman Siswa Pematangsiantar that can be attributed to the relationship between the two variables.

The determination coefficient $(\mathrm{R}$ square $)=\mathrm{R}^{2}=(0,338)^{2}=0,114$

From the computation above, the obtained determination coefficient ( $\mathrm{R}$ square) is 0.114. This means that more or less $11,4 \%$ of the variation in students' rewriting of the story in film variable $(\mathrm{X})$ and the vocabulary mastery variable $(\mathrm{Y})$, while the rest $(100 \%-11,4 \%$ $=88,6 \%$ ) was probably due to other factors such as the students' motivation, their interest in learning writing, their health or frame of mind on the day they took the test, the frequency of practice, their writing habit, etc. This indicates that of the relationship existing between students' mastery of past tense and their ability in writing recount text, as much as $11,4 \%$ 
can be explained by the correlation between the two variables, while the remaining $88,6 \%$ can be attributed to other factors mentioned above.

\subsection{Result}

The research findings indicate that there is a significant correlation between students' rewriting of the story in film variable $(\mathrm{X})$ and the vocabulary mastery variable $(\mathrm{Y})$. From the statistic analysis, it was found out that there was a positive correlation between students' rewriting of the story in film variable $(\mathrm{X})$ and the vocabulary mastery variable (Y). It was proved by the value of $r_{x y}$ of the correlation was greater than $r$ table. The value of $r_{x y}$ was 0.338. When we consulted it to the $r$ table with $\mathrm{N}=60$, we found that $\mathrm{r}$ table had a value 0.211 . It could be seen obviously that the value of $r_{x y}$ is greater than the $r$ table. These facts imply that students' rewriting of the story in film variable $(\mathrm{X})$ give a useful contribution in their ability the vocabulary mastery variable (Y).

\section{Conclusion}

Based on the result of the study, it can be concluded as follows:

a. From table 1 it can be concluded that the average score of that students' rewriting of the story in film variable (X) is 67,56 ( $4054: 60)$. Six students $(10 \%)$ get excellent level, 13 students $(21,6 \%)$ get very good, 13 students $(21,6 \%)$ get good, 8 students $(13,33 \%)$ get fair, 11 students $(18,33 \%)$ get poor and 9 students $(15 \%)$ get very poor.

b. The average score of the students' ability in writing recount text is 71, 52 (4291: 60). Five students $(8,33 \%)$ get excellent level, 11 students $(18,33 \%)$ get very good, 20 students ( 33,3\%) get good, 14 students ( 23,3\%) get fair, 7 students $(11,6 \%)$ get poor and 3 students $(5 \%)$ get very poor.

c. There is a significant correlation between students' rewriting of the story in film variable $(\mathrm{X})$ and the vocabulary mastery variable $(\mathrm{Y})$. This result is obtained from the computation of the correlation between students' rewriting of the story in film variable $(\mathrm{X})$ and the vocabulary mastery variable $(\mathrm{Y})$ applied to the sample is 0.338 (from the calculation). The critical value of the Pearson $\mathrm{r}$ with the $5 \%$ significant level is 0.211 (From the table of statistical book). It means that the result obtained from the computation is greater than its critical value. Therefore, the writer concludes that the correlation between the two variables above is highly significant.

\section{References}

Andriana, Klara. 2007. Implementing Multiple Intelligences in Teaching Narrative Writing. Universitas Pendidikan Indonesia.

Brown, H.D. 2001. Teaching By Priciples: An Interactive Approach to Language Pedagogy. USA: Addison Wesley Longman, Inc.

Danan M. 2004. Captioning and Subtitling: Undervalued Language Learning Strategies. [Online]. Available at: http://www.erudit.org/revue/meta/2004/v49/n1/009021 ar.html.

Ermayanti, Dewi. 2006. The Correlation between Students' Vocabulary Mastery and Their Reading Comprehension Score in TOEIC. Universitas Pendidikan Indonesia.

Farhady, Hossein \& Evelyn Hatch. 1982. Research Design and Statistics for Applied Linguistics. Newburry House Publishers, Inc. Rowley. Massachusetts.

Fatriyani, Eva. 2004. The Correlation Between Students' Self-Esteem in Learning English and Their Speaking Achievement. Universitas Pendidikan Indonesia. 
Figg S. 2006. Understanding Narrative Writing: Practical Strategies to Support Teachers. [Online]. Available at: Http: //wwwfp. Education. tas.gov.au/ English/ narrative. htm.

Geddes M. \& Sturtridge G. 1982. "Video in the Language Classroom." Practical Language Teaching. Heinemann Educational Books.

Ghaith, Ghazi.2002. The Problem of Teaching Writing. American University of Beirut (online). Available at: http://nadabs.tripod.com/writing/.

Hafniati, Sari, R., and Pujiastuti, S. (2020). Developing of Thesaurus Software to Increase the Writing Quality of the Thesis of the Students at the German Language Department. Britain International of Linguistics, Arts and Education (BIoLAE)Journal Vol.2 (1):346-352.

Harris, David. 1969. Teaching English as a Second Language. McGraw Hill Book Company. George Town University New York.

Kim, Miyoun (Sophia). 2006. Genre-Based Approach to Teaching Writing online). Available at: http:// web1. hpu. edu/ images/ GraduateStudies/ TESL _WPS /07 Kim_ Genre_a17238.pdf.

Konskinen S. Patricia \& Friends. 1996. "Captioned Television and the Vocabulary Acquisition of Adult Second Language Correlational Falicity Residents". Journal of Educational Technology Systems. 24 (4) 359 -373.

Lever H.J. (no date). MA Translation \& Interpreting. [Online]. Available at: http://www.peak-translations.co.uk/ChapterTwo-Subtitling.doc.

Lonergan J. 1984. Video in Language Teaching. Cambridge University Press.

McGovern J. 1983. Video Application in English Language Teaching (ELT Documents: 114). Pergamon Press Ltd. and the British Council.

Setiawandi D. 2006. The Effectiveness of Conversations and Pictures in Improving Students' Vocabulary Mastery. Universitas Pendidikan Indonesia.

Siregar, M., and Haswani, F. (2020). Learner Types and Their Preferences in Learning English. Budapest International Research and Critics in Linguistics and Education (BirLE) Journal Vol 3 (2): 777-783.

Stempleski S. \& Tomalin B. 1990. Video in Action (Recipes for Using Video in Language Teaching). Prentice Hall International English Language Teaching.

Sugiyono, 2007. Metode Penelitian Pendidikan Pendekatan Kuantitatif, Kualitatif, dan R\&D. Alfabeta.

Suniarti, Siti. 2006. The Effectiveness of Teaching Vocabulary Using Total Physical Response Story Telling (TPRS) Method in Second Grade of SMPN 6 Bandung. Universitas Pendidikan Indonesia.

Wahana Komputer. 2007. Panduan Praktis Pengolahan Data Statistik dengan SPSS 15.0. Wahana Komputer\&Penerbit Andi

Watson Robert. 1990. Film and Television in Education: An Aesthetic Approach to the Moving Image. The Falmer Press. 